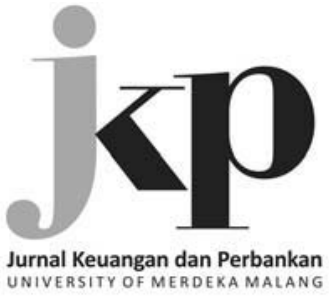

UNIVERSITY OF MERDEKA MALANG

Article history:

Received: 2018-02-27

Revised: 2018-03-01

Accepted: 2018-04-09
I Gusti Ayu Purnamawati (Indonesia)

\section{Individual Perception of Ethical Behavior and Whistleblowing on Fraud Detection through Self-Efficacy}

\begin{abstract}
This study aims to determine individual perceptions of ethical behavior and whistleblowing on fraud detection through self-efficacy. Study on the banking sector in Bali Province. This study uses a quantitative approach. Sampling method using simple random sampling method, with the number of samples that is 70 respondents. Whistleblowers are employees and or stakeholders who see some wrong actions can be independent and without published report the action to the company's management without fear of mutual action. The type of data in this study is primary data. The data were collected by using questionnaires. Measurement using a Likert scale. Analysis of research data using hierarchical regression analysis model. The results showed: (1) individual perceptions about ethical behavior have no effect on fraud detection; (2) whistleblowing and self-efficacy have a positive and significant effect on fraud detection; (3) self-efficacy does not succeed in moderating the relationship between individual perceptions of ethical behavior toward fraud detection; and (4) self-efficacy does not moderate the relationship between whistleblowing to fraud detection.
\end{abstract}

Keywords: Ethical Behavior; Fraud; Self-efficacy; Whistleblowing

\section{JEL Classification: M51; O15}

Citation: Purnamawati, I. G. A. (2018). Individual perception of ethical behavior and whistleblowing on fraud detection through self-efficacy. Jurnal Keuangan dan Perbankan, 22(2), 362-372. https://doi.org/10.26905/ jkdp.v22i2.1991.

\begin{abstract}
Abstrak
Penelitian ini bertujuan untuk mengetahui persepsi individu mengenai perilaku etis dan whistleblowing pada pendeteksian fraud melalui self-efficacy. Studi pada sektor perbankan yang ada di Provinsi Bali. Penelitian ini menggunakan pendekatan kuantitatif. Metode pengambilan sampelnya menggunakan metode simple random sampling, dengan jumlah sampel yaitu 70 responden. Whistleblower merupakan pegawai dan atau pemegang saham yang melihat beberapa tindakan yang salah dapat secara independen dan tanpa dipublikasikan melaporkan aksi tersebut kepada manajemen perusahaan tanpa takut adanya aksi timbal balik. Jenis data dalam penelitian ini adalah data primer. Pengumpulan data dilakukan dengan menggunakan kuesioner. Pengukuran dengan skala Likert. Analisis data penelitian menggunakan model analisis regresi berjenjang. Hasil penelitian menunjukkan: (1) persepsi individu mengenai perilaku etis tidak berpengaruh terhadap pendeteksian fraud; (2) whistleblowing dan self efficacy berpengaruh positif dan signifikan terhadap pendeteksian fraud; (3) selfefficacy tidak berhasil memoderasi hubungan antara persepsi individu mengenai perilaku etis terhadap pendeteksian fraud; dan (4) self efficacy tidak berhasil memoderasi hubungan antara whistleblowing terhadap pendeteksian fraud.
\end{abstract}

Kata Kunci: Perilaku Etis; Fraud; Self-Efficacy; Whistleblowing 


\section{Individual Perception of Ethical Behavior and Whistleblowing on Fraud Detection through Self-Efficacy}

I Gusti Ayu Purnamawati

Currently, the problem of corruption is still one of the global topics in various countries. Whistleblowing system is one of the solutions to many cases of corruption (Hakim, Subroto, \& Andayani, 2017). The perpetrator of fraud can be from within or from outside the organization and can be done by management and employees (Karyono, 2013). The importance of whistleblowing to detect and uncover wrongdoing within an organization has been recognized by many regulators around the world. Whistleblowing is an attempt to achieve an economic and social objective, so the culprit expects support from various parties to achieve that goal. Whistleblowing system is a system of prevention and identification of fraud that will occur in an organization or company. To run this system required an active role of employees. This is because ordinary people can not be whistleblowers, only people within the organization can do so (Gaurina, Purnamawati, \& Atmadja, 2017). Whistleblowing policy became the main topic after the discovery of several cases such as Enron, WorldCom, Anderson, and Tyco which then pushed the US capital market regulator to issue Sarbanes Oxley Act of 2002 (Stigliano, 2011). Despite increasing support and incentives for whistleblowing, there generally remains reluctance to blow the whistle. Lee \& Xiao (2018) review the determinants of internal and external whistleblowing on accounting-related misconduct, U.S. whistleblowing legislation on accountingrelated misconduct and related research, and the effects of whistleblowing on firms and whistleblowers. Within each area, suggestions for future research are offered. Based on the case example it is seen that the involvement of employees who know the ins and outs of fraud within the company is very important because the job desk or employee duties are always associated with job desk or tasks that understand the flow of cash flow, balance sheet, or balance within the company. While recognizing that whistleblowing is a powerful tool to prevent and detect malpractices, very few decided to blow the whistle due to the fear of retaliation, legal li- abilities, and cultural oppositions. These barriers should be removed to internalize whistleblowing as a positive means of improving transparency in the organizations, over and above the government as a whole (Razak, Noor, \& Zakaria, 2015).

In general, whistleblowing can be viewed as an act of exposing, reporting, revealing, malpractices, and misconduct. Whistleblowing is also seen as a source of evidence for the detection of malpractices (Dyrmishi, Hroni, \& Gjokutaj, 2013). Also, it is viewed as individual's performance of his or her duty to curb official abuses of entrusted power for private gain (Sama, 2014). The globalizing affirmation of understanding organization as networks, of nations such as good governance, and of the norm of efficiency, also globalizes the perceived necessity of whistle-blower protection and policies. This is the reason why many and historically very different countries today have whistleblowing legislation or are debating them. Not because the notion of whistleblowing has been translated to those specific national contexts and cultures, but because the discourse about organizations has seeped through despite cultural and national specificities (Gasparski, 2017).

According to Zimbelman et al. (2014), there are several elements for whistleblowing systems to function effectively, anonymity, independence, access, and follow-up. Mustapha \& Siaw (2012) states that whistleblowing is a complex process involving personal and organizational factors. According to (Lee \& Fargher, 2018), there are two types of whistleblowing, namely internal whistleblowing and external whistleblowing. A whistleblower is an employee who makes an unauthorized disclosure of information about criminal or malpractices, along channels that are not specified. The term is quintessentially English derived from the practice of police officers blowing their whistles to alert colleagues and the public when they saw a crime committed and needed assistance (Sama, 2014). Accord- 


\section{Jurnal Keuangan dan Perbankan | PERBANKAN}

Vol. 22, No. 2, April 2018: 362-372

ing to Tjahjono et al. (2013), the whistleblower is an employee and/or stakeholder who sees some wrong actions can be independently and without publication report the action to the company's management without fear of mutual action.

This study aims to examine whether self-efficacy influence relationship between individual perception about ethical behavior and whistleblowing to fraud detection

\section{HYPOTHESES DEVELOPMENT}

Perception is a process of giving meaning to the environment by individuals. According to Griffin \& Ebert (2004), ethical behavior is a behavior that conforms to generally accepted social norms concerning correct and correct actions. Individuals that believe that ethical behavior ensures positive results were found to be positively and significantly related to whistleblowing intent. Despite the influence of top management to report fraudulent revenues, idealistic individuals obligations to act morally conflicts with the idea that they will follow the tone set from management and hence will be more willing to blow the whistle (Brink, Cereola, \& Menk, 2015). Vadera, Aguilera, \& Caza (2009), argue that the integration of the whistle-blowing research with that on ethics programs will aid in systematically expanding our understanding of the situational antecedents of whistle-blowing. They conclude of their review by discussing new theoretical and methodological areas of research in the domain of whistleblowing.

A study by Najahningrum (2013) shows that there is no influence on the organizational ethical culture and fraud in the government sector. Therefore, the influence of the ethical culture in organizations on employees' responses need to be analyzed regarding wrongdoing. In-depth analysis of corporate ethical culture dimensions related to varied responses by the employees are required (Kaptein, 2011). Ogungbamila (2014) in Nigeria indicated that country's CPI scores increased with the percentage of individuals who whistle blew corrupt acts. Curtis \& Taylor (2009) found that locus of control was a significant antecedent to whistleblowing intentions among U.S. public accountants.

$\mathrm{H}_{1}$ : individual perceptions of ethical behavior have a positive and significant effect on fraud detection

There are many factors that affect a person to decide to become a whistleblower, such as internal factors and external factors. Through the individual factor, itself can be seen that the life of a person brings influence also to his perspective to see the environment and respond to the problems that occur. Thus, the perception of a person becomes an important component to be considered in support of whistleblowing this system. Whistleblowers have helped to root out fraud, often leading to significant settlements, but the fact remains that serious organizational wrongdoing appears to be growing, not diminishing (Shawver, 2011). Whistleblowers are ostracized and isolated for identifying wrongdoings. Despite this deterrent, the whistleblowers have not recoiled.

Nonetheless, organizations need to develop an ethical corporate culture, where employees become 'ethical partners' and do the right thing, not because they have to, but because they want to (Farooqi, Abid, \& Ahmed, 2017). Paeth (2013) on the contrary, believes that the moral complexity of whistleblowing in context of corruption in the organizations has to be considered from other aspects as well. Researchers still need to find an answer as to why some people are ready to blow whistle toward wrongdoings and why the others decide to remain aloof or silent (Reckers-Sauciuc \& Lowe, 2010).

$\mathrm{H}_{2}$ : individual perception of whistleblowing has a positive and significant effect on fraud detection 
Fraud detection is an act of knowing that fraud is happening, ready the offender, who the victim is, and what causes it. The key to fraud detection is to be able to see errors and irregularities. Although there are uncertain signs or symptoms of fraud, every fraud is always followed by signs. Therefore, by recognizing the symptoms can recognize the signal or recognize the existence of fraud indications (Karyono, 2013). Previous research on whistleblowing, fraud detection, self-efficacy, and ethical behavior was undertaken by Nixson et al. (2013), Waytz, Dungan, \& Young (2013), and Noviani \& Sambharakreshna (2014),

$\mathrm{H}_{3}$ : self-efficacy has a positive and significant effect on fraud detection

Bandura (1997) states that self-efficacy beliefs enable the requisite control for the human agency one's ability to self-regulate behavior. Thus, how people behave can often be better predicted by their beliefs about their capabilities rather than their actual capabilities. This is because self-efficacy perceptions help determine what individuals do with the knowledge and skills they have. Self-efficacy beliefs are impacted through mastery experiences, vicarious experiences provided by social models, social persuasion through positive appraisals, and physiological and psychological arousal (Palmer, 2013).

$\mathrm{H}_{4}$ : $\quad$ self-efficacy has a positive and significant effect on the relationship between individual perceptions of ethical behavior with fraud detection

Narayana \& Juliarsa (2016) states that selfefficacy is a person's belief that he/she can accomplish a job at a certain level that affects personal activity towards the achievement of goals. Self-efficacy can come from various sources of self-experience, the experience of others, verbal persuasion, physiological, and psychological condition. Individu- als with high self-efficacy will tend to be more courageous to disclose the fraud that occurs in their organization because they have confidence in their abilities (MacNab \& Worthley, 2008). This is supported by the opinion of Purnomo \& Lestari (2010) that self-efficacy plays an important role in ethical behavior in an organization (Hidayati \& Pustikaningsih, 2016). Previous research on whistleblowing, fraud detection, self-efficacy, and individual perception was undertaken by Ghani (2013), Ahmad et al. (2014), Jefri \& Mediaty (2014), Erwin (2015), dan Gaurina, Purnamawati, \& Atmadja (2017).

$\mathrm{H}_{5}$ : $\quad$ self-efficacy has a positive and significant effect on the relationship between individual perception of whistleblowing with fraud detection

\section{METHODS}

This research was conducted on the banking sector in Bali Province. Among them are 6 rural banks in Bali. This research uses quantitative approach because of the research data in the form of numbers and analysis using statistics (Sugiyono, 2014). The test equipment used in this study is hierarchical regression analysis to determine the dependence of a dependent variable with independent variables, the classical assumption test is a requirement to perform multiple regression analysis. In this study, the sample used simple random sampling method, because the sampling of population members is done randomly without considering the strata in the population (Sugiyono, 2014). The total sample is 70 peoples from 6 BPR (in department accounting, finance, human resource, and operational). BPR Padma (15 respondents), BPR Nur Abadi (10 respondents), Kanaya BPR (10 respondents), BPR Dewata Candra (10 respondents), BPR Parasari (10 respondents), and BPR Nusamba (15 respondents). 


\section{Jurnal Keuangan dan Perbankan | PERBANKAN}

Vol. 22, No. 2, April 2018: 362-372

Table 1. Research Variables and Operational Definition

\begin{tabular}{|c|c|c|}
\hline Variable & Definition & Indicator \\
\hline $\begin{array}{l}\text { Individual Perceptions of } \\
\text { Ethical Behavior }\left(X_{1}\right)\end{array}$ & $\begin{array}{l}\text { Ethical behavior is a behavior that } \\
\text { conforms to generally accepted social } \\
\text { norms concerning correct and correct } \\
\text { actions (Griffin \& Ebert, 2004) }\end{array}$ & $\begin{array}{l}\text { Elements of a code of conduct consisting of a } \\
\text { company's code of conduct, the employee's } \\
\text { general behavior; activities, occupations and } \\
\text { outside positions of directors; with clients } \\
\text { and suppliers; dealing with outside people } \\
\text { and organizations; swift communication; and } \\
\text { privacy and secrecy (Arens, Elder, \& Beasly, } \\
2008 \text { ) }\end{array}$ \\
\hline $\begin{array}{l}\text { Individual Perception of } \\
\text { Whistleblowing }\left(X_{2}\right)\end{array}$ & $\begin{array}{l}\text { A good whistleblowing program can be a } \\
\text { very effective tool in detecting and } \\
\text { preventing fraud (Zimbelman et al., 2014). } \\
\text { Individual perception of the } \\
\text { whistleblowing system is an employee's } \\
\text { perspective on how he sees or views a } \\
\text { fraud complaint system that serves to } \\
\text { complain of fraudulent acts committed by } \\
\text { the internal company. }\end{array}$ & $\begin{array}{l}\text { Structural aspects of whistleblowing system, } \\
\text { operational aspects of whistleblowing } \\
\text { system, and aspects of whistleblowing } \\
\text { system care Gaurina, Purnamawati, \& } \\
\text { Atmadja, 2017) }\end{array}$ \\
\hline Fraud Detection $(Y)$ & $\begin{array}{l}\text { Fraud detection is an act of knowing that } \\
\text { fraud is happening, ready the offender, } \\
\text { who the victim is, and what causes it. The } \\
\text { key to fraud detection is to be able to see } \\
\text { errors and irregularities (Karyono, 2013) }\end{array}$ & $\begin{array}{l}\text { Fraud indicators are accounting peculiarities, } \\
\text { weaknesses of internal control, } \\
\text { deviations/oddities of analysis, excessive } \\
\text { lifestyles, unusual behavior, and complaints } \\
\text { (Gaurina, Purnamawati, \& Atmadja, 2017) }\end{array}$ \\
\hline
\end{tabular}

Self-Efficacy

Self-efficacy is the belief of a person that
he/she can accomplish the work at a
certain level that affects the personal
activity towards the achievement of the
goal (Bandura, 1993) in (Narayana \&
Juliarsa, 2016)

Confidence to complete difficult work, ability to achieve predetermined goals, confidence to be able to work effectively (Chen, Gully, \& Eden, 2001) Juliarsa, 2016)

The questionnaire is a technique of data collection conducted by giving a set of questions or written statement to the respondent to answer (Sugiyono, 2014). In this study, the distributed questionnaire has four items of questions addressed to employees at the existing BPR in the Province of Bali. This questionnaire or list of statements contains an individual's perception of ethical behavior and whistleblowing, and fraud detection, as well as self-efficacy, using the Likert model attitude scale. Likert scale is used to measure attitudes, opinions, and perceptions of a person or group of people about social phenomena. In the research instrument, the researcher uses 5 Likert scales to know individual perception about ethical behavior and whistleblowing, fraud detection, that is strongly agreed, agree, neutral, disagree, and strongly disagree.
Data analysis technique: (1) hypothesis testing, moderation effect test, and main effect in research done by using moderation regression analysis through a method called hierarchical regression analysis. This method requires two regression equations, the first containing only the main effects and the second containing the main effects and moderation effects. The form of multiple regression equations in this research:

$$
\begin{aligned}
& Y=\alpha+\beta_{1} X_{1}+\beta_{2} X_{2}+\beta_{3} X_{3}+e . \\
& Y=\alpha+\beta_{1} X_{1}+\beta_{2} X_{2}+\beta_{3} X_{3}+\beta_{4} X_{1}{ }^{*} X_{3} \beta_{5} X_{2}{ }^{*} X_{3} \\
& +\mathrm{e}
\end{aligned}
$$

Where:

$\mathrm{Y}=$ fraud detection

$\alpha \quad=$ constanta 
$X_{1}=$ individual perceptions of ethical behavior

$\mathrm{X}_{2} \quad$ = individual perception of whistleblowing

$\mathrm{X}_{3}=$ self-efficacy

$\beta \quad=$ regression coefficient

$\mathrm{e} \quad=$ error

(2) Validity test, a questionnaire is said to be valid if the question on the questionnaire is able to reveal something that will be measured by the questionnaire (Ghozali, 2013). To determine the level of validity, the study used the program assistance Statistical Product and Service Solutions (SPPS) Version 19; (3) reliability test, a questionnaire is said to be reliable, one's answer to the question is consistent or stable over time. A variable is said to be reliable if it gives a Cronbach Alpha value > 0.70; (4) classic assumption test: (a) normality test, aims to test whether the regression model, the dependent variable with the independent variable has a normal or abnormal distribution; (b) multicollinearity test, to know the presence or absence of multicollinearity can be seen from the value of tolerance and the opponent of variance inflation factor (VIF); and (c) heteroscedasticity test, aimed to test whether in the regression model there is uniformity variation from residual one observation to another observation; (5) determination coefficient test $\left(R^{2}\right)$, is used to measure how far the ability of the model in explaining the variation of the dependent variable; and (6) hypothesis testing, partial test $\left(\mathrm{t}_{\text {test }}\right)$, basically shows how far the influence of one independent variable individually in explaining the dependent variable. This test is done by using significance level 0.05 ( $\alpha=5$ percent).

\section{RESULTS}

In this study, the number of samples $(n)=70$ and the magnitude of $\mathrm{df}$ can be calculated 70-2=68 with $\mathrm{df}=68$ and alpha $=0.05$ obtained $\mathrm{r}_{\text {table }}$ of 0.235 with a two-sided test. Based on the result of statistical data, it can be seen on individual perception variable about ethical behavior $\left(X_{1}\right)$, individual perception about whistleblowing $\left(X_{2}\right)$, self-efficacy $\left(X_{3}\right)$, and fraud detection $(\mathrm{Y})$ that $\mathrm{r}_{\text {count }}$ for each question item more large from $\mathrm{r}_{\text {table }}$ of 0.235 (5 percent significance level with $n=68$ ), so that all question items are declared valid. Based on the reliability test results of each variable shows the value of Cronbach Alpha greater than 0.70 , so it can be concluded that the instrument used in this study is reliable. Individual perceptions of ethical behavior (0.847); individual perception of whistleblowing (0.771); selfefficacy (0.906); and fraud detection (0.907).

The statistical test results show that the value of Kolmogorov Smirnov is 0.597 and significant at 0.869 . This means that a significant value of 0.869 is greater than 0.05 , which means the $\mathrm{H}_{0}$ is accepted or the residual data is normally distributed, so the regression model can be said to meet the assumption of normality.

Based on multicollinearity test results indicate that the tolerance value of each independent variable used in this study indicates a number greater than 0.10, $X_{1}(0.677), X_{2}(0.737)$, and $X_{3}(0.875)$. The VIF value of each independent variable shows a number smaller than $10, X_{1}(1,478), X_{2}(1,357)$, and $X_{3}(1,142)$, so it can be concluded that there is no multicollinearity.

Based on the result of heteroscedasticity test that the value of significance is greater than 5 percent $(0.05)$. This shows that there are no symptoms of heteroscedasticity. The results of heteroscedasticity testing for variables $X_{1}(0.117), X_{2}(0.070)$, and $X_{3}(0.786)$.

\section{Regression Test Results}

\section{Testing model 1}

Analysis Regression Model 1 results in Table 2.

Based on the test results from Table 2 can be made a model of regression equation as follows: Fraud Detection $=2,721-0,038 \mathrm{X}_{1}+0,073 \mathrm{X}_{2}+1,222 \mathrm{X}_{3}+\mathrm{e}$ 


\section{Jurnal Keuangan dan Perbankan | PERBANKAN}

Vol. 22, No. 2, April 2018: 362-372

From the equation above, it can be explained as follows: (1) constant value of 2.721 means: if individual perception about ethical behavior $\left(X_{1}\right)$, whistleblowing $\left(X_{2}\right)$, and self-efficacy $\left(X_{3}\right)$ equal to zero, then fraud detection value $(\mathrm{Y})$ is 2.721 ; (2) the value of individual perception regression coefficient on ethical behavior $\left(X_{1}\right)$ is -0.038 means that any decrease of individual perception about ethical behavior hence fraud detection will decrease by 0.038 assuming other independent variable constant. The value of $t$-count is -1.260 and the significance value of $0.212>0.05$ means that $\mathrm{H}_{1}$ is unacceptable; (3) the value of the individual perception regression coefficient on whistleblowing $\left(X_{2}\right)$ is 0.073 means that an increase of individual perception about whistleblowing then the detection of fraud will increase by 0.073 with the assumption of other independent variables constant. The value of $t-{ }_{\text {count }}$ is 2.098 and significance value is $0.040<0.05$ means that $\mathrm{H}_{2}$ is accepted; and (4) the value of regression coefficient of individual perception about self-efficacy $\left(X_{3}\right)$ is equal to 1.222 means that every increase of self-efficacy then fraud detection will increase equal to 1.222 with the assumption of other independent variable is constant. The value of $t$-count is 45.438 , and the significance value is $0.000<0.05$ means that $\mathrm{H}_{3}$ is accepted.

\section{Testing model 2}

From the equation above, it can be explained as follows: (1) constant value of -6.483 means, if individual perception about ethical behavior $\left(X_{1}\right)$, whistleblowing $\left(X_{2}\right)$, and self-efficacy $\left(X_{3}\right)$ equal to zero, then the value of fraud detection $(\mathrm{Y})$ is -6.483 ; (2) the value of regression coefficient of individual perception about ethical behavior $\left(X_{1}\right)$ is equal to 0.050 meaning that every increase of individual perception about ethical behavior hence fraud detection will increase equal to 0.050 assuming other independent variable constant. The value of $t$ count of 0.613 and the value of significance of $0.542>0.05$ means $\mathrm{H}_{1}$ is not acceptable; (3) the value of individual perception regression coefficient on whistleblowing $(\mathrm{X} 2)$ is 0.170 means that any increase of individual perception about whistleblowing then fraud detection will increase by 0.170 with the assumption of other independent variable constant.

The value of $\mathrm{t}$-count of 2.276 and significance value of $0.026<0.05$ means that $\mathrm{H}_{2}$ is accepted; (4) the value of regression coefficient of individual perception about self-efficacy $\left(X_{3}\right)$ is equal to 1.793 means that every increase of self-efficacy then fraud detection will increase equal to 1.793 with assump-

Table 2. Results of Multiple Linear Regression Test

\begin{tabular}{|c|c|c|c|c|c|}
\hline \multirow[t]{2}{*}{ Model } & \multicolumn{2}{|c|}{$\begin{array}{l}\text { Unstandardized } \\
\text { Coefficients }\end{array}$} & \multirow{2}{*}{$\begin{array}{c}\begin{array}{c}\text { Standardized } \\
\text { Coefficients }\end{array} \\
\text { Beta }\end{array}$} & \multirow[t]{2}{*}{$\mathbf{t}$} & \multirow[t]{2}{*}{ Sig. } \\
\hline & B & Std. Error & & & \\
\hline (Constant) & 2.721 & 1.711 & & 1.590 & 0.117 \\
\hline Individual Perception & -0.038 & 0.030 & -0.031 & -1.260 & 0.212 \\
\hline Whistleblowing & 0.073 & 0.035 & 0.049 & 2.098 & 0.040 \\
\hline Self-efficacy & 1.222 & 0.027 & 0.975 & 45.438 & 0.000 \\
\hline
\end{tabular}

Table 3. Results of Multiple Linear Regression Test

\begin{tabular}{lcccrrr}
\hline \multirow{2}{*}{ Model } & \multicolumn{2}{c}{$\begin{array}{c}\text { Unstandardized } \\
\text { Coefficients }\end{array}$} & $\begin{array}{c}\text { Standardized } \\
\text { Coefficients }\end{array}$ & t & Sig. \\
\cline { 2 - 5 } & B & Std. Error & Beta & & -1.481 & 0.144 \\
(Constant) & -6.483 & 4.378 & & 0.613 & 0.542 \\
Individual Perception & 0.050 & 0.081 & 0.040 & 2.276 & 0.026 \\
Whistleblowing & 0.170 & 0.075 & 0.115 & -193 & 0.000 \\
Self-efficacy & 1.793 & 0.249 & 1.430 & -1.183 & 0.241 \\
Indv.Percept*Self-eff. & -0.005 & 0.004 & -0.213 & -1.737 & 0.087 \\
Whistblw*Self-eff. & -0.007 & 0.004 & -0.250 & & \\
\hline
\end{tabular}


tion other independent variable constant. The value of $t$ count is 7.193 and significance value is $0.000<$ 0.05 means that $\mathrm{H}_{3}$ is accepted; (5) the value of individual perception regression coefficient on ethical behavior $\left(X_{1}\right)$ is -0.005 means that any decrease in ethical behavior then fraud detection will decrease 0.005 assuming other independent variables are constant. The value of $t$-count is -1.183 and significance value that is $0.241>0.05$ means that $\mathrm{H}_{4}$ is unacceptable; and (6) the value of individual perception regression coefficient on whistleblowing $\left(\mathrm{X}_{2}\right)$ is -0.007 means that any decrease in individual perception about whistleblowing then fraud detection will decrease by 0.007 assuming other independent variables are constant. The value of $\mathrm{t}$-count is -1.737 and significance value that is $0.087>0.05$ means that $\mathrm{H}_{5}$ is unacceptable.

\section{Determination Coefficient Test $\left(\mathbf{R}^{2}\right)$}

Based on the test result of model 1 indicates that the adjusted $\mathrm{R}$ square is 0.972 . This reflects that 97.2 percent of fraud detection variables can be explained by individual perception variables regarding ethical behavior, whistleblowing, and self-efficacy. While the rest of 12.8 percent is explained by other factors outside the research variables. Based on the results of testing model 2 shows that the value of adjusted $R$ square is 0.974 . This reflects that 97.4 percent of fraud detection variables can be explained by individual perceptual variables regarding ethical behavior, whistleblowing, and self-efficacy. While the rest of 12.6 percent is explained by other factors outside the research variables.

\section{Simultaneous Test Results ( $\boldsymbol{F}_{\text {Test }}$ )}

Based on the data analysis model 1 obtained a significance value of 0.000 smaller than 0.05 . This shows that the variable of individual perception about ethical behavior, whistleblowing, and selfefficacy simultaneously have a positive and significant effect on fraud detection. Based on the data analysis model 2 obtained significance value of 0.000 smaller than 0.05 . This shows that the variable of individual perception about ethical behavior, whistleblowing, and self-efficacy simultaneously have a positive and significant effect on fraud detection.

\section{DISCUSSION}

The results showed that the individual's perception of ethical behavior did not affect fraud detection. The result of this research is not consistent with the research by that is the variable of ethical behavior have a positive and real effect on the detection of fraud and fraud prevention. The results of this study do not support the theory of Arens, Elder, \& Beasly (2008) which states that the most effective way to prevent cheating is to apply ethical behavior in organizations (companies). Understanding and applying the concept of ethical behavior and values that are used as guidance in the organization (company) can support a conducive atmosphere and help minimize the occurrence of fraud.

The results showed that whistleblowing and self-efficacy had a positive and significant effect on fraud detection. This research is consistent with that done by. The results of this study do not support the Ancient Theory (2015), which is the method used in conducting fraud detection through internal complaints, which must be supported by the existence of a whistleblowing system. Zimbelman et al. (2014) explain that the importance of detecting fraud is more proactive by installing a grievance channel to receive reports of fraud. Thus the proactive whistleblowing encourages the participation of individuals within the company to be more daring to report the occurrence of fraud. This research is consistent with that done by (Hidayati \& Pustikaningsih, 2016) that self-efficacy has a positive effect on the intention to conduct whistleblowing. Individuals with high self-efficacy will tend to be more courageous to disclose the fraud that occurs in the environment of the organization because he 


\section{Jurnal Keuangan dan Perbankan | PERBANKAN}

Vol. 22, No. 2, April 2018: 362-372

has confidence in their ability (MacNab \& Worthley, 2008). This is supported by the opinion of MacNab \& Worthley (2008) that self-efficacy plays an important role in ethical behavior in an organization. The results showed that self-efficacy did not succeed in moderating the relationship between individual perceptions of ethical behavior toward fraud detection (Orhan \& Ozyer, 2016). There are significant relationships between self-efficacy and whistleblowing. The sample of the study was limited to university students due to problems of time and cost and for the sake of analyzing the sector of education. The results of this study are not consistent with research by Nugroho (2015) and Hidayati \& Pustikaningsih (2016). Thus, the abler an employee to behave ethically then it does not affect the tendency of employees to be able to detect cheating, because individuals with high self-efficacy are not necessarily more courageous in expressing the fraud that occurred in the environmental organization. The results showed that self-efficacy did not moderate the relationship between whistleblowing to fraud detection. This research is not consistent with that done by Nugroho (2015). Proactive whistleblowing can encourage individual participation in companies to be more daring to report fraud. From Global Corruption Barometer (2013) data, it can be seen that fraud cases are still common in Indonesia. Cases of corruption can be prevented by the role of the public as the discloser of a fraud case (whistleblower). According to the Association of Certified Fraud Examiners (ACFE), that with the application of whistleblowing system, the number of corporate losses and the fraud detection period becomes smaller.

\section{CONCLUSION AND SUGGESTIONS}

\section{Conclusion}

Based on the statistic analysis, individual perceptions about ethical behavior do not affect fraud detection; whistleblowing, and self-efficacy have a positive and significant effect on fraud detection.
Self-efficacy does not succeed in moderating the relationship between individual perceptions of ethical behavior toward fraud detection; Self-efficacy does not moderate the relationship between whistleblowing to fraud detection. So it can be concluded, that the existence of a proactive whistleblowing system will encourage employee participation companies to be more daring to report the occurrence of fraud within the organization (company). The presence of whistleblowing systems brings significant changes for the company because of the benefits of employees indirectly can supervise each other. The enforcement of existing whistleblower rules, especially of credible protection schemes for whistleblowers and the communication channel for whistleblowing should be strengthened. These efforts include developing ethical compliance codes and promoting activities that establish a corporate in encourages employee whistleblowing and other appropriate professional behaviors. By understanding whistle-blowing systems as desired by society, the legitimacy theory could be transferred to the whistleblowing concept (Pittroff, 2014).

\section{Suggestions}

Whistleblowing, for that stuff, reported or reported should be accompanied by goodwill with the purpose to bring the company in a better direction, not to complain or report a personal complaint or be based on a bad intention to dropping someone. The application of whistleblowing system will be successful if followed by a good internal control within the company. The people who manage the system this should be those who are independent and not affected by anyone, and which then follow up the employee complaint. The company must assure protection against employees who provide information by maintaining the confidentiality of employees it also provides an incentive (reward) or bonus to the employee as a form of appreciation for his actions. 


\section{REFERENCES}

Ahmad, S. A., Yunos, R. M., Ahmad, R. A., \& Sanusi, Z. M. (2014). Whistleblowing behaviour: The influence of ethical climates theory. Procedia-Social and Behavioral Sciences, 445450.

Arens, A. A., Elder, R. J., \& Beasly, M. S. (2008). Auditing dan jasa assurance: Pendekatan terintegrasi (Alih Bahasa: Herman Wibowo). Jakarta: Erlangga.

Bandura, A. (1993). Perceived self-efficacy in cognitive development and functioning. Educational Psychologist, 28(2), 117-148.

Bandura, A. (1997). Self-Efficacy: The Exercise of Control. New York: Worth Publisher.

Brink, A. G., Cereola, S. J., \& Menk, K. B. (2015). The effects of personality traits, ethical position, and the materiality of fraudulent reporting on entry-level employee whistleblowing decisions. Journal of Forensic $\mathcal{E}$ Investigative Accounting, 7(1), 180-211.

Chen, G., Gully, S. M., \& Eden, D. (2001). Validation of a new general self-efficacy scale. Organizational Research Methods, 4(1), 62-83.

Curtis, M. B., \& Taylor, E. Z. (2009). Whistleblowing in public accounting: Influence of identity disclosure, situational context, and personal characteristics. Accounting and The Public Interest, 9, 191-220.

Dyrmishi, A., Hroni, E., \& Gjokutaj, E. (2013). Whistleblowers Protection in Albania: An Assessment of the
Legislation and Practice. Institute for Democracy and Mediation.

Erwin, J. (2015). Whistleblowing environment in Indonesian financial institutions. International Journal of Business and Social Research, 5(11), 28-35.

Farooqi, S., Abid, G., \& Ahmed, A. (2017). How bad it is to be good: Impact of organizational ethical culture on whistleblowing (the ethical partners). Arab Economic and Business Journal, 12(2), 69-80.

Gasparski, W. W. (2017). Whistleblowing: In Defense of Proper Action $18^{\text {th }}$ Ed. London: Routledge.

Gaurina, N. P. M., Purnamawati, I. G. A., \& Atmadja, A. W. T. (2017). Pengaruh persepsi karyawan mengenai perilaku etis dan whistleblowing system terhadap pencegahan fraud (studi kasus pada Bali Hai Cruises). E-Journal S1 Ak Universitas Pendidikan Ganesha, 8(2).

Ghani, N. A. (2013). Predicting whistle-blowing intention in Malaysia: Evidence from manufacturing companies. Dissertation. Curtin University. Curtin University.

Ghozali, I. (2013). Aplikasi analisis multivariate dengan program IBM SPSS 21 update PLS regresi. Semarang: Badan Penerbit Universitas Diponegoro.

Griffin, R. W., \& Ebert, R. J. (2004). Business ( $7^{\text {th }}$ Ed.). New York: Prentice Hall.

Hakim, T. I. R., Subroto, B., \& Andayani, W. (2017). Faktor situasional dan demografis sebagai prediktor niat individu untuk melakukan whistleblowing. Jurnal Ilmiah Administrasi Publik (JIAP), 3(2), 124-133.

Hidayati, T. H., \& Pustikaningsih, A. (2016). Pengaruh komitmen profesi dan self efficacy terhadap niat untuk melakukan whistleblowing. Jurnal Nominal, 5(1), 97-108.

Jefri, R., \& Mediaty. (2014). Pendeteksian kecurangan (fraud) laporan kauangan. Jurnal Akuntansi, 1(2), 56-64.

Kaptein, M. (2011). From inaction to external whistleblowing: The influence of the ethical culture of organizations on employee responses to observed wrongdoing. Journal of Business Ethics, 98(3), 513-530.

Karyono. (2013). Forensic Fraud. 1st Ed. Yogyakarta: ANDI.

Lee, G., \& Fargher, N. (2018). The role of the audit committee in their oversight of whistle-blowing. A Journal of Practice $\mathcal{E}$ Theory, 37(1), 167-189.

Lee, G., \& Xiao, X. (2018). Whistleblowing on accounting-related misconduct: A synthesis of the literature. Journal of Accounting Literature, 41, 22-46.

MacNab, B. R., \& Worthley, R. (2008). Self-Efficacy as an intrapersonal predictor for internal whistleblowing: A US and Canada examination. Journal of Business Ethics, 79(4), 407-421.

Mustapha, M., \& Siaw, L. S. (2012). Will final accountancy students whistle blow? A Malaysian case. International Journal of Trade, Economics, and Finance, 3(5), 327-331. 


\section{Jurnal Keuangan dan Perbankan | PERBANKAN}

Vol. 22, No. 2, April 2018: 362-372

Najahningrum, A. F. (2013). Faktorfaktor yang mempengaruhi fraud: Persepsi pegawai Dinas Provinsi DIY. Accounting Analysis Journal, 2(3), 259-267.

Narayana, A. A. S., \& Juliarsa, G. (2016). Kompleksitas tugas sebagai pemoderasi pengaruh orientasi tujuan dan self-efficacy pada audit judgment. Jurnal Ilmiah Akuntansi dan Bisnis, 11(1), 28-40.

Nixson, Kalo, S., Kamello, T., \& Mulyadi, M. (2013). Perlindungan hukum terhadap whistleblower dan justice collaborator dalam upaya pemberantasan tindak pidana korupsi. USU Law Journal, 1(2), 40-56.

Noviani, D. P., \& Sambharakreshna, Y. (2014). Pencegahan kecurangan dalam organisasi pemerintahan. Jurnal JAFFA, 2(2), 61-70.

Nugroho. (2015). Pengaruh persepsi karyawan mengenai whistleblowing system terhadap pencegahan fraud dengan perilaku etis sebagai variabel intervening pada PT Pagilaran. Tesis. Universitas Negeri Yogyakarta.

Ogungbamila, B. (2014). Whistleblowing and anti-corruption crusade: Evidence from Nigeria. Canadian Social Science, 10(4), 145-154.

Orhan, U., \& Ozyer, K. (2016). I whistleblow as I am a university student: An investigation on the relationship between self-efficacy and whistleblowing. International Journal of
Business Administration and Management Research, 2(1), 2833.

Paeth, S. R. (2013). The responsibility to lie and the obligation to report Bonhoeffer's what does it mean to tell the truth? And the ethics of whistleblowing. Journal of Business Ethics, 112(4), 559-566.

Palmer, N. (2013). The effects of leader behavior on follower ethical behavior: Examining the mediating roles of ethical efficacy and moral disengagement. Dissertation. The University of $\mathrm{Ne}$ braska.

Pittroff, E. (2014). Whistle-blowing systems and legitimacy theory: A study of the motivation to implement whistle-blowing systems in German organizations. Journal of Business Ethics, 124(3), 399-412.

Purnomo, R., \& Lestari, S. (2010). Pengaruh kepribadian, self-efficacy, dan locus of control terhadap persepsi kinerja usaha skala kecil dan menengah. Jurnal Bisnis dan Ekonomi (JBE), 17(2), 144-160.

Razak, S. N. A. A., Noor, W. N. B. W. M., \& Zakaria, M. (2015). Breaking the silence: The efficacy of whistleblowing in improving transparency. Scientific Research Journal (SCIRJ), 3(4), 35-39.

Reckers-Sauciuc, A. K., \& Lowe, D. J. (2010). The influence of dispositional affect on whistle-blowing. Advances in Accounting, Incorporating Advances in International Accounting, 26(2), 259269.
Sama, H. K. (2014). Breaking the silence: Efficacy of whistleblowing in public procurement. Global Journal of Contemporary Research in Accounting, Auditing, and Business Ethics (GJCRA), 1(1), 248-262.

Shawver, T. J. (2011). Can ethics education impact whistleblowing? Management Accounting Quarterly Summer, 12(4), 29-37.

Stigliano, A. L. (2011). Sarbanes-Oxley and Corporate Greed. University of Connecticut.

Sugiyono. (2014). Metode Penelitian Kuantitatif Kualitatif dan RED. Bandung: Alfabeta.

Tjahjono, S., Untung, B., Tarigan, J., Efendi, J., \& Hardjanti, Y. (2013). Business Crime and Ethics: Konsep dan Studi Kasus Fraud di Indonesia dan Global. 1st Ed. Yogyakarta: ANDI.

Vadera, A. K., Aguilera, R. V., \& Caza, B. B. (2009). Making sense of whistle-blowing's antecedents: Learning from research on identity and ethics programs. Business Ethics Quarterly, 19(4), 553586.

Waytz, A., Dungan, J., \& Young, L. (2013). The whistleblower's dilemma and the fairness-loyalty tradeoff. Journal of Experimental Social Psychology, 49(6), $1-7$.

Zimbelman, M. F., Albrecht, C. C., Albrecht, W. S., \& Albrecht, C. O. (2014). Akuntansi Forensik (Forensic Accounting). $4^{\text {th }} \mathrm{Ed}$. Jakarta: Salemba Empat. 